$$
\begin{aligned}
& \frac{7}{10} \\
& \cdot \frac{1}{6} \\
& \frac{1}{+} \\
& \frac{1}{8} \\
& 0
\end{aligned}
$$

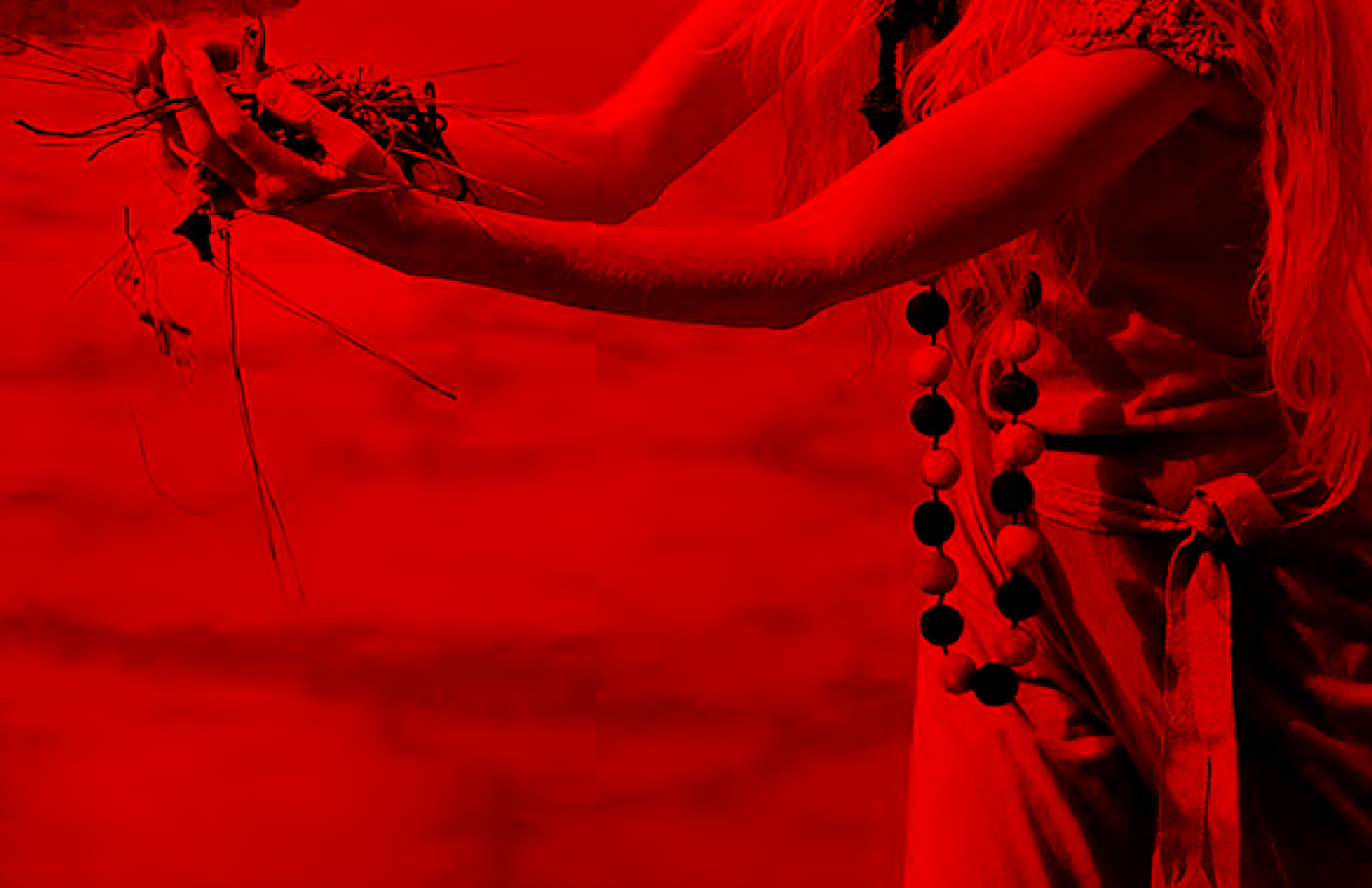




\section{A moda como comunicação}

Gabriela Soares Cabral - Assistente editorial sênior https://orcid.org/0000-0002-3410-3839

Valéria Faria dos Santos Tessari - Editora-executiva http: //orcid.org/0000-0002-7959-909X

Maria Claudia Bonadio - Editora-chefe

https://orcid.org/0000-0001-9704-9780

O número 31 da dObra[s], a primeira edição do ano de 2021, está no ar. Ainda nos encontramos em meio à pandemia, o que exige maior dedicação e esforço de toda a equipe envolvida na produção da revista e de suas colaboradoras e seus colaboradores, a quem mais uma vez só temos a agradecer.

Nesta edição, apresentamos o dossiê Sentido(s) da moda, resultado da colaboração binacional entre as pesquisadoras Ana Claudia Mei Alves de Oliveira (PUC-SP: FAFICLA: Programa de Estudos Pós-Graduados em Comunicação e Semiótica - Brasil) e Giulia Ceriani (Università de Bergamo, Itália), no qual reunimos 15 artigos que, por meio da teoria semiótica estrutural ou discursiva, investigam as dimensões socioeconômicas, político-culturais, estéticas-estésicas no âmbito interdisciplinar da moda. 0 dossiê também traz a resenha de Raffaella Scelzi sobre as afinidades da moda e da semiótica na obra italiana La moda fra senso e cambiamento. Teorie, oggetti, spazi (2020), escrito por Izabella Pezzini e Bianca Terracciano.

Esta edição ainda conta com discussões acerca das fronteiras de gênero nos textos submetidos em fluxo contínuo e reunidos na seção Artigos.

Em É Vossa Excelência pela adoção da jupe-culotte? Escândalo e modelagem em 1911, Fausto Viana e Isabel Cristina Italiano investigam o burburinho causado pela moda que invadira a cidade de São Paulo em 1911, a jupe-culotte, traje que já circulava pela Europa e também causou estardalhaço ao ser usada por senhoras do Rio de Janeiro. Além disso, os autores também desvendam a modelagem da peça, desenvolvida a partir de manuais, revistas e exemplares do período disponíveis em diversos museus da Europa e dos Estados Unidos.

Já o texto Miss Brasil Gay Juiz de Fora: os trajes típicos e suas mulheres imaginadas de 2017 a 2019, de Paulo de Oliveira Rodrigues Jr., aborda o traje típico desfilado pelas concorrentes ao Miss Brasil Gay, concurso realizado desde 1977 que elege o mais belo transformista gay do país. Essa etapa do evento corresponde à representação dos aspectos culturais dos Estados brasileiros pelas misses: demonstra que na competição as identidades regionais nem sempre encontram-se em primeiro plano, mas sim na construção de uma 
feminilidade exuberante. 0 autor também destaca o papel dos estilistas dentro do concurso, uma vez que seus imaginários e modos de fazer definem, frequentemente, as narrativas imagéticas apresentadas pelas participantes.

A edição também traz a tradução para o português de Maria Cristina Volpi e Carolina Casarin para o artigo Lustro, laca e Liotard: técnicas e texturas entre Ásia e Europa. A superfície brilhante à moda da China é um fenômeno de crossmedia. 0 texto em questão aborda como a circulação das chinoiseries está relacionada com as ambições diplomáticas e econômicas entre países asiáticos e europeus, de modo que a Europa transformou seu universo sensorial ao buscar dominar técnicas que imitassem o brilho das superfícies de objetos importados da China ou do Japão.

Na seção Resenhas apresentamos dois textos. O primeiro, de Mara Rúbia Sant'Anna, sobre o livro Estudos de indumentária e moda no Brasil: tributo a Sophia Jobim organizado por Maria Cristina Volpi e Madson de Oliveira. Publicada em 2019, a obra é fruto do evento homônimo realizado pelo Núcleo Interdisciplinar de Estudos da Imagem e do Objeto (NIO), do Programa de Pós-Graduação em Artes Visuais da Escola de Belas Artes da Universidade Federal do Rio de Janeiro (UFRJ), que também contou com uma exposição da coleção Sophia Jobim realizada nas dependências do Museu Histórico Nacional. Ao reunir pesquisas de nove autores, o volume traça, por meio das práticas e trajetórias da primeira professora de indumentária da Escola de Belas Artes do Rio de Janeiro, novos rumos para a história da moda no Brasil e no mundo.

A segunda resenha que compõe a seção é de autoria de Fernanda Bonizol, que analisa o livro A elegância do agora, de Costanza Pascolato, publicado em 2019. A autora destaca como, por seus relatos autobiográficos, a colunista da revista Vogue fornece suas impressões sobre a moda. Dona de uma longa trajetória pelo mundo da moda brasileira, Costanza Pascolato e seu livro contribuem para a compreensão de comportamentos, aparência e distinção nesse universo.

Por fim, os textos desta edição são acompanhados por duas séries de fotografias de Rogério D’Avila Ortiz. As imagens compõem um estudo que busca ressaltar as experiências advindas do encontro entre as artesãs Donna Liu e Marlene Leopoldino e o estilista Romero Souza.

Além de registrar nosso agradecimento mais profundo a todas e todos que dedicaram tempo e energia para a produção deste número, queremos fazer um agradecimento especial à Ana Claudia Mei Alves de Oliveira, organizadora brasileira deste dossiê. Ana Claudia tem todo o nosso respeito e a nossa admiração e estamos orgulhosas de poder contar com a sua presença e o seu trabalho na dobra[s].

Boa leitura. 